\title{
Interrogating the Revenue Allocation in Intergovernmental Relations, Fiscal Federalism and Local Government Finance in Nigeria
}

\author{
Bolanle W. Shiyanbade ${ }^{1}$ \\ ${ }^{1}$ Department of Public Administration, Obafemi Awolowo University, Ile-Ife, Nigeria \\ Correspondence: Bolanle W. Shiyanbade, Department of Public Administration, Obafemi Awolowo University, \\ Ile-Ife, Nigeria. Tel: 234-80-3411-5043. E-mail: shiyanbola@ymail.com
}

Received: October 5, 2016 Accepted: November 19, $2016 \quad$ Online Published: October 30, 2017

doi:10.5539/par.v6n2p71 URL: http://dx.doi.org/10.5539/par.v6n2p71

\begin{abstract}
This study examined the relationship between fiscal federalism, governance and local government finances in Nigeria, focusing on the administration of local governments and other subsidiary issues on revenue generation in the country. It analysed the legal, institutional and procedural mechanisms for administration, as well as assessed the effect of intergovernmental relations on local government under federal system of governance in the country. This is with a view to providing information on revenue allocation and intergovernmental relations as important elements in understanding and addressing the fiscal federalism on local council finance in Nigeria in the context of their divergent governance experiences since the fourth republic.

The paper discovered that beyond the function of revenue generation or allocation, fiscal relations influenced governance positively by creating the expediency of transparency and responsiveness in government as well as a corresponding three levels of government has responsibilities and roles to play in the lives of citizenry in order to bring governance to the grassroots. However, the work found evidences of lack of fiscal autonomy and independent of local government as well as delay in local government election has resulted to poor performance of local administration in Nigeria at large. The results also revealed that a very important factor affecting the local government administration in Nigeria still remains the overbearing contribution of about $93 \%$ oil revenue to the national income; a situation that, both state and local governments in Nigeria cannot generate up to twenty five percent $(25 \%)$ of their expenditure and poor tax culture amongst the citizenry. The study concluded among others that effective human resources, improved strategy, and enhanced capacity building, are critical to improved revenue generation and allocation, which in turn could go a long way to alleviating good governance in Nigeria.
\end{abstract}

\section{Introduction}

There is no gain saying that federalism has been a commonly used term in serious theological works since the $17^{\text {th }}$ century (prior to the political use). It finds expression in ecclesiology (the doctrine of the church) as well as church governance that drew upon concepts of covenants. The term "federalism" still looms large in current political debates. Its importance is traceable to its primary feature especially that has to do with the distribution of power. The problem of defining or conceptualising it has been due to such factors as its importance, several varieties of political arrangements to which the term has properly been applied (Elazar, 1977 as cited by Adesopo, 2007) and the dramatic changes in the institution to which it refers (Ricker, 1975 as cited in Adesopo). To date, there is no clear or universally acceptable meaning. More often than not, the definitions are given by stating its characteristics. According to Akindele (1995), the concept is not free from the problems of definitional pluralism as common to others of its type within the eclectic scholarship of political science.

In spite of these, attempts have been made by some scholars to define the subject. Basically, the word federal is derived from the latin word "fidere" meaning "to trust". Federalism is the idea of a group or body of members that are bound together (latin: foedus, covenant) (Elazar and Kincaid, 1980) with a governing representative head which may be a King or God (as in theology), or a thing or general assembly (as in politics). Federalism is the political philosophy that underlies a system of government in which sovereignty is constitutionally divided between a central governing authority and constituent units, creating what is called a federation (Wikipedia, http://en.wikipedia.org/wiki/federalism). Federalism has to do with the need of people and polities to unite for common purposes and at the same time remaining separate in order to preserve their respective integrities. In the 
words of Elazar (1987:33) as cited in Adesopo (2007),

Federal principles grow out of the idea that free people can freely enter into lasting yet limited political associations to achieve common ends and protect certain rights while preserving their respective integrities. Federalism is also said to be concerned simultaneously with the diffusion of political power in the name of liberty and its concentration on behalf of unity or energetic government. In its broadest sense, federalism is a form of justice, emphasising liberty and citizen participation in governance, but one which is inevitably linked to political reality because it must still be concerned with the distribution of powers.

It is not unfair to say that federalism is designed to achieve some degree of political integration based on a combination of self-rule and shared rule. As for Dunmoye (2002) quoted in Omoleke (2000), federalism is not a political ideology, it is a product of necessity. He added that it has emerged as a particular kind of political and functional arrangement between ethnic communities or disparate peoples for living and working together nationally, while preserving a measure of separate identity. To Jinadu (1979), federalism is a form of governmental institutional structure deliberately designed to cope with the twin, but difficult, task of maintaining unity while also preserving diversity.

This definition agrees with that of Elaigwu (1994) who simply described a federal system of government as one that arises from the desire of people to form a union without loosing their identity. Elaigwu further described it as a compromise in a multinational state between two types of determination - the determination to maintain a supranational framework of government which guarantees security for all in the state, nation or the nation - state on the one hand and the self-determination of component groups to retain their individual identities on the other hand. These scholars emphasise identity or rather diversity just as Akinyemi (1979) pointed out that federalism represents a structural balancing of interests. To him, federalism is an admission of differences and interests which may be difficult to subject to a central government.

In the same vein, Wheare (1964) (as cited by Jinadu, 1979; Akindele, 1995; Dunmoye 2002; Adesopo 2007) who is popularly referred to as the father of (modern) federalism, sees federal system as the method of dividing power so that general and regional governments are each, with a sphere, coordinate and independent. His recognition in the field has been because Wheare generated the attributes of federalism which have continued to form the bedrock of all federal polities. These attributes include:

i. the division of governmental responsibilities between levels of government;

ii. a written constitution spelling out this division and from which federal and state authorities derive their powers;

iii. a judiciary independent of both levels of government that acts as an arbiter in cases where there are conflicts over the jurisdictions enumerated in (i) above; and

iv. the federal arrangement emphasising co-equal supremacy of the various levels each in its respective field of operation and the citizens of the federation being concurrently under two authorities and owing loyalties to them (Wheare, 1964).

\section{Intergovernmental Relations (IGR)}

The subject of IGR has generated long-standing interest, indeed constant and pervasive controversy, throughout political and administrative history of a country. It is basically the subject of how governments deal with each other as well as their relative roles, responsibilities and levels of influence are and should be. Attempts to define IGR often result in controversy because IGR doesn't have precise definition. For instance, Adamolekun (2002) defines IGR as the interactions between the different levels of government within a state. This definition rests on wrong assumption that in any modern society, governmental systems are broken down into tiers. This definition seems to be relevant only in a federal set-up. Under this set-up, IGR is dominated by the relationship between the central government and the subunits as clearly spelt out in the constitution. He then added that the emphasis is usually on federal-regional relations which include how both levels relate to the local governments established within the region.

Substituting the word "state" for "regional", the pattern of relationship that is obtained looks like this: federal-state; federal-state-local; federal-local; inter-state; state-local; and inter-local (Wright, 1980; Ayoade, 1980; Adamolekun, 1983 cited in Adesopo, 2007). The assumption here is that the governmental systems are broken down into independent tiers. Such an assumption seems to neglect the fact that it is not in all modern states that the governmental systems are arranged in tiers. This is especially where a unitary system of government is being run with little or no belief in the philosophy of separation of powers. With this, IGR takes 
place in a unitary system of government, depending on the conception of IGR that is preferred.

This brings us to specific references to IGR and federalism which can only be said to be similar and related. This falls in line with an assertion credited to Bamidele (1980) who describes IGR as not synonymous with federalism but that both are related. This relationship relies upon what originates the formation of the federation. From this sense, Ayoade (1980) gave two main types of federation: aggregative and disaggregative federations. Shedding more light, he described the former as one in which previously sovereign states come together to form a federation. This situation may arise because of the feeling of mutual indispensability. Such an arrangement is often built on the desire to cooperate and the advantages of the federation to the units are derived mainly from such cooperation.

Consequently, positive IGR is a precondition for the formation of the federation. On the other hand, (i.e. disaggregative federation) is one that grows out of the unitary state. The simple feature of a unitary state is its composition that is usually diverse in nature and the type of federation that grows out of it is bound to be based on hatred and jealousy, as described by Ayoade, and as such federalism might have been endorsed to guarantee self-realisation. In a sense, disaggregative federation contradicts unity. It is a well-known fact that IGR gets conditioned by the nature of federation and in this latter type, IGR is minimal and can hardly be cordial because of the minimal nature of the common cause (Adesopo, 2007).

In addition, IGR can be said to be an aspect of federalism especially when it is viewed from its contribution to the study of federalism. Ayoade (1980) believe that IGR encompasses more than what is usually conveyed by the concept of federalism as the emphasis is chiefly on nation-state relationships with occasional attention to inter-state relationship. Apart from this, it includes all the permutations, combinations and intricacies of relations among the levels of government (Hahn and Levine, 1980).

In defining IGR, Anderson (1960) as quoted by Omoleke (2000) and Adesopo (2007), lays emphasis on human interactions in any governmental set-up either horizontal or vertical relationship. According to him, IGR are relations among human beings "clothed with office". He argues persuasively that there is no IGR per se but there are only relations among human beings, clothed with office. In essence, human beings, in his view, are the real determinants of what relations among governmental units would look like. Since the concept of government as an institution is an inanimate and intangible set up, IGR must be seen in terms of human behaviour and interactions.

In his contribution, Ayo (1986), in agreeing with Anderson's view, asserted that IGR represents the interactions at various levels that take place among government officials. Furthermore, Olowu (1979) summarises IGR in Nigeria as follows:

Relationships among governments in Nigeria generally tend to be vertical rather than horizontal and have alternated between hierarchical subordination under the military rule and conflicts under civilian regimes.

By this, he must be sharing the same view with Tarlton (1965) as cited by Adesopo (2007) who sees federal-state relationship as symmetrical, if there is uniformity in the profile of relations between the central government and each of the constituent state governments, while it is asymmetrical if disparity characterises the pattern of relations between the central government and each of the component state governments. Agreeing with these two authors, the sharing of power and responsibility calls for cooperation and coordination vertically and horizontally among governments in the federation but at the same time it also provides a breeding ground for conflicts and encourages rivalry and competition among governments as actors within the system.

According to Omoleke (2000), a descriptive analysis of IGR in the federal states that ignores conflict, rivalry and competition but concentrates on cooperation is perhaps inadequate. This must have been borne out of the belief that although the constitution spells out the division of responsibilities among the tiers of government, it is most unlikely to carry out such division such that each performs its specific functions adequately without cutting across the other. This must have informed Aremu's suggesting working out cooperative arrangement. According to Aremu (1980), the theoretical formal division of powers is not completely with operating responsibilities as the levels of government interpenetrate one another in many places and ways (as cited by Omoleke, 2000).

Bartholomew (1972), looking at the real problems of public administration vis-a-vis the relationship between administrative levels or units that enjoy a certain degree of autonomy, also suggested cooperative relationship among the levels of government for efficient administration. These are, by implication, suggesting cooperative federalism.

Watts (1972) and Awa (1976) however contend that the term interdependent federalism is preferable as cooperative federalism is said to be a tautology. Inherent in this preferred term are cooperation, bargaining and 
conflict, and all these find their roots in the key word "interaction" that describes IGR. Conflicts arise mainly when the central government and the state and/or local governments disagree about the limits of their own authority and such other matters as policy on labour, social welfare and economic regulation, among others.

To resolve the jurisdictional disputes, the units find it necessary to recognise their interdependence, and resort to bargaining. What this gives rise to is cooperation which can take the form of project grants, special allocations of revenue and responsibilities, technical assistance from federal to state governments and informal exchanges and loans of expert personnel during peak or crisis periods and sharing of centrally revenues as well as spelling out of jurisdictional power of each tier, and a host of other areas.

However, Olugbemi (1980) as quoted in Adesopo (2007) was emphatic in saying that IGR is not all-cooperative venture among interacting units, it manifests intra-systemic conflicts also as typified by the constant wrangling over relative share of the tax field, governmental powers and functions, the quantity of allocated funds as well as the unending search for an acceptable revenue-sharing formula among (Nigeria's) governments. He quickly added that, despite these, we should not dismiss the network of cooperative efforts and consultations which feature continually in inter-jurisdictional transactions.

\section{Intergovernmental Fiscal Relations in Nigeria}

Most of the arguments in Nigeria over the fiscal relationships between the federal and constituent levels of government have centered on the question of revenue allocations between the different parts of the country and the principles upon which distributions should be based. These principles became a major cause of the inter-regional rivalry and conflict which have dominated Nigerian politics, particularly before 1966 . The literature is replete with the adverse effect of oil revenue on intergovernmental relationships in Nigeria (Olaiya, 2009).

For instance wrote that since oil revenue dominates Nigeria's Federation Account the sharing of oil rents govern intergovernmental fiscal relations in the country with an on-going tension between agitations by oil producing states for greater share of resources and demands for redistribution from other regions, particularly relatively less endowed ones (Oyefusi, 2007 cited in Olaiya, 2009). In the political arena, the division of intergovernmental fiscal relationship between the federal government and the states has been a major source of contention, in the same vein as the little revenue flowing to the state and local level. Between the late 1970s to date there have been at least a minimum of forty litigations between the federal government and the states on issues of allocation (Malemi, 2006). Before 1952 central allocations to the regions were made on the basis of derivation, with 'each region receiving grants in strict proportion to the contribution which it made to central revenues' (Smith, 1981 cited in Olaiya, 2009).

Thus, the history of successive revenue allocation arrangements in Nigeria has been most unstable and accompanied by distrust, inadequate information flows, a lack of transparency, and uncertain accountability (Olaiya, 2009). Ahmed and Singh, (2003) argue that the present intergovernmental fiscal arrangement prevailing in Nigeria generates a large vertical imbalance in favour of the center while allocations to the states do not depict any clear pattern of redistribution between regions or any correlation with relative needs. They also posited that while in theory the arrangement takes into account the effort of each state to mobilize internal revenue, in practice, an equal weight is given for this variable in allocations. Thus, apart from failing to create an incentive to increase states' efforts at revenue generation, the federation transfer does not appear to have any significant equalization effect.

\section{Revenue Allocation and Fiscal Federalism in Nigeria}

In Nigeria, Tax administration and revenue collection functions are performed by different institutions at the two tiers of government and local government (Olaiya, 2009). At the federal level, Federal Ministry of Finance; the Federal Inland Revenue Service and the Nigeria Customs Service are responsible for the administration of tax laws and revenue collection. The Joint Tax Board is responsible for harmonising the relationship between tax authorities at the federal and state levels. The National Revenue Mobilisation, Allocation and Fiscal Commission propose the remuneration of political and judicial office-holders, and also advise on the allocation of revenues among the three tiers of government (Olaiya, 2009). The state's Board of Internal Revenue and Ministry of Finance are responsible for tax administration at the state level.

The revenue committee for local governments and Finance and Supply Department are responsible for tax matters at the local government level. Efficiency and effectiveness of Nigeria's tax system over the years has been faced with a number of challenges. These challenges include:

i. Tax Administration and administrative challenges; these include inadequate personnel and institutional 
capacity to administer taxes effectively. The use of poorly trained staff with inadequate technical and administrative competences is not uncommon especially at the local government level.

ii. Compliance challenges i.e. the failure of employers to keep accurate records and remit all Personal Income Tax (PIT) to relevant authorities remains a challenge in spite penalties and the payment of all tax arrears by defaulters. Also some business concerns keep different versions of record at times all certified by auditors. The correct version is different from the version for the tax authority. There is yet another robust version for the bank showing a buoyant business. Also, most tax-payers have limited ability of to keep accurate accounts and are ignorant on their tax responsibilities.

iii. Lack of reliable statistics on the various taxpayers is a major hindrance for the identification and assessment of taxpayers. This lack of data limits follow up to enforce collection.

iv. Lack of equality especially in PIT is major problem of taxation in Nigeria. Self- employed outnumber paid workers and they earn as much as four times that of the formal sector employees, the bulk of PIT is paid by employees whose salaries are deducted at source (Mamud, 2008).

v. There are over 500 different taxes and levies imposed by various tiers of government in Nigeria instead of only those approved by Taxes and Levies (Approved list of Collection) Act.

vi. Fraud and Corruption on the part of tax-collecting institutions is an issue that needs to be addressed. Revenue Collectors still engage in fraudulent practices, in spite of the various control measures and the presence of Independent Corrupt Practice Commission (ICPC), the Economic and Financial Crime Commission (EFCC), and in 1986, the introduction of the Structural Adjustment Programme (SAP). In order to address the above challenges the federal government has adopted several measures which lead to a new National Tax Policy (NTP) was approved by the Federal Government of Nigeria in January 2010 , to provide a set of rules and guidelines that will regulate all stakeholders such as taxpayers, regulators, tax practitioners and legislator. The policy is also expected to uphold the application of fiscal federalism in the generation and expenditure of revenue by governments at all levels as stipulated by the Nigerian constitution.

TelIa (1999) identifies two types of federalism namely, the dual federalism and the cooperative federalism. For the dual federalism, the constitution created two separate and independent tiers of government with their own clearly defined areas of responsibilities. In such a system, it is inevitable that a certain level of tension and competition would exist. Cooperative federalism, on the other hand, simply refers to making federalism work through cooperation between the various levels of government. It emphasizes the partnership between the different levels of government providing effective public services for the nation. This type of federalism is practiced in the United States of America and Germany. Nigeria too has been practicing cooperative federalism since the military incursion of in the strong central government approach, the federal government retains the lion share of revenue and the state and local governments have smaller share out of the federation account.

In the decentralized approach, the federal government retains a lower share, with states and local governments having a larger share out of the federation account (Likita, 1999). On the other hand, confederation is a loose form of federalism that allows citizen from each region to maintain their primary allegiance to the region to which they belong. Confederation allows each region to retain and utilize revenue generated from within its jurisdiction (Okoh, 2004 and Olaiya, 2009). Earlier, Mbanefoh (1993) argues that, it may be practically impossible to satisfactorily balance the financial resources of a segment of a federation with the functions which it is expected to perform. This imbalance (Okeke, 2004) concluded should not be regarded as result of federalism, but as a result of the disturbances of the equilibrium which ordinarily would allow the segments of the federation to carry out developmental programs that could be undertaken with the available internal resources.

Nigeria was incorporated in 1914 with the amalgamation of the two British protectorates of Northern and Southern Nigeria and the Crown Colony of Lagos into a single entity. The concept of fiscal federalism was first introduced in Nigeria in 1946 with the formation of a federation of three regions by splitting of the Southern Province to create the Eastern and Western Regions, and the Northern Region which was a continuation of the Northern Province, following the adopting of the Richards Constitution (Olaiya, 2009). Each of the three regions (East, West and North) has its own revenue base with a relatively weak Federal Government Taxation, Revenue Allocation, and Fiscal Federalism in Nigeria (Barkan, 2001; Vincent, 2002; Olaiya, 2009).

The Nigerian federal system metamorphosed thereafter from a two- tiered federal arrangement initially comprising three unequal political and administrative regions to the current three tiered federal system of 36 states, one Federal Capital Territory and 774 Local Governments. Before the military took over government in 
1966, the regions were powerful and autonomous, especially as they generated most of their revenue from independent sources. Nowadays, the sub-national governments are totally dependent on federally collected revenues (Barkan, 2001; Mfor, 2009; Olaiya, 2009).

According to Nwabuese (1983), true federalism presupposes that the national and regional governments should stand to each other in a relation of meaningful independence resting upon a balanced division of powers and resources. Conversely, most analysts including the opinion that Nigeria stopped operating a truly federal system of government in January 1966 in favour a unitary system of government, in July 2010, the Nigeria's 1999 constitution was amended (Vincent, 2002). Unfortunately, expected changes especially the issues "true federalism" were not made. One thing that can make or mar the corporate existence of Nigeria is the status of oil producing states, the way and form of allocating funds to oil producing areas from the federation account is very controversial.

Government established Federation Account in order to disburse the funds to the beneficiaries (Federal, State and Local Governments) in line with the constitution and approved revenue allocation formula. The disbursement of this fund is done by the Federation Account Allocation Committee (FAAC). FAAC made up of Minister of States for Finance, Accountant general of the Federation, Commissioners of Finance of the 36 states of the federation and representatives of other institutions meets monthly. In 1963 constitution, the local government was treated implicitly as part of the regional governments. The 1979, 1989 and 1999 federal constitutions identified functions of each level of the federation.

These functions are contained in various lists tagged Exclusive, Residual, and Concurrent. The Exclusive list contains function to be performed solely by the federal government. These functions include: external affairs, issue of legal tender currency, police, defense accounts of government of the federation etc. The Concurrent legislative lists are those to be performed by both federal and state governments. These include census, higher education, industrial development prisons, National Parks and Antiquities etc. While the Residual list contains functions to be performed to the exclusive reserve of the state government. It is also important to state that the functions of Local Government are clearly stated. For instance, the functions and roles of the local government are listed in the fourth schedule of the 1979, 1989 and 1999 federal constitutions. The main functions of local governments are provision of public goods, cemetery, refuse disposal public convenience, naming of roads, streets and house numbering, licensing, regulation and control of the sale of liquor, collection of rate, radio and television license etc.

\section{Local Governments Finance in Nigeria}

Since the majority of the local councils lack the capacity to raise Internally Generated Revenue (IGR) to a reasonable level, it has to depend upon the federal allocation for her performance (Shiyanbade, 2016). The inability of the councils therefore to generate revenue meant for its continued functions and operations had largely contributed to its total reliance and dependence upon the federal statutory allocation to remain relevant as a tier of government in the Nigeria federal system. For effective performance, the local government will not only be assigned functions, but fund enough to enhance its service delivery to the clientele (Shiyanbade, 2016). The lack of adequate fund affects the operation of the local councils, invariably painting a very ugly picture of the system. This is probably why Nwaka (2006:20) as cited in Shiyanbade (2016) argued that:

The provision of $20 \%$ for local governments in the revenue allocation formula of the federation's account remains a tragic reminder of the lack of political will to appropriately address the problem of local representations and effective delivery of services. As the government that has the most direct and immediate impact on the people, it stands to reason that adequate funding should ordinarily be guaranteed for this tier of government. Many local governments are rural based and naturally has limited capacity for internally generated revenue. It is expected that local government should actually be the engine of growth for local economics but regrettably the hegemonic central of the revenue from the federation account by the state government and the federal government is not indicative of a genuine desire to strengthen the local government to meet the high expectation of the mass of the people.

The argument above supports adequate funding for the local government, which is a positive step towards improving the financial base of the local councils in the federation. Onah (2004) observed that "the local governments are heavily deprived of funds which they could use in development pursuit is no longer news. The skewed administration of the state-local government joint account in favour of the state totally explains the deprivation. The local government due of the federal allocation is tampered with by the state, and in some states, the revenue-yielding resources are also taken over by the state". 
Ojugbeli and James (2014) as cited in Shiyanbade (2016) argued that the issue of joint account had facilitated all manner of deductions from council allocation. Consequently, this brings inefficiency to the local government system, obstructs local governments from taking quick decisions, and disallows them from embarking on useful projects as well as rescuing mission of any epidemic diseases which might break out in their areas (Lamidi and Fagbohun, 2013 as cited in Shiyanbade, 2016).

However, under the military administration, the functions of each tier of government are not clearly defined. The function of each level of government depends on the Head of State and Commander-in-chief of the Armed forces. The military governments rely on decrees and various ad-hoc provisions to assign responsibilities. Even under the civilian dispensation, the local governments are still subject to varying degrees of state oversight and control, even though their functions are specified in the Fourth Schedule. The Local Government Authorities (LGAs) can exercise their authority only in accordance with enabling legislation passed by the states.

Furthermore, most of the powers accorded to the states in the Second Schedule of the 1999 constitution (as amended) are exercised concurrently with the federal government. However, there is the confusion over which tier of government, federal or state, is best equipped to deal with various areas of policy. At the moment, the federal and states government complement each other in the area of Intergovernmental relations, Revenue Allocation, and Fiscal Federalism in Nigeria provision of health and education. In practice, the functions on the concurrent list lead to wasteful duplication and inter-unit competition which hinder the effective functioning of the federal structure.

\section{Conclusion}

This scholarly foray into extant literature has been able to produce far-reaching conclusions. One is that "not even a single one" of the 21 countries focused whose economies are dominated by revenue from oil "is a democracy". Oil states are deficient of the "connective tissues" to society that induce political accountability. Scholars have demonstrated how 'oil price shock' affected Nigeria's economic governance by adversely impacting on macroeconomic activities like the general output level, inflation rate, money supply, and real exchange rate (Olaiya, 2009).

The study also recommended that local governments need to pay more attention to internally generated revenue in order to avoid over reliance on allocation from federation account. This is imperative for the development of infrastructure, agriculture, human capital, employment generation and the provision of essential services to the people at the grassroots by the local government councils Shiyanbade (2016).

The period since then also saw a geometric increase in the quantity and cost of governance, although without visible qualitative impact on the citizenry. Poverty has shown a consistent rising trend. The proportion of Nigerians living in poverty increased from $28 \%$ in 1980 to $66 \%$ in 1996 to about $70 \%$ in 2000 . Whereas, some have concluded that despite the stupendous oil wealth 'Nigeria appears not to have progressed since 1974'. In the final analysis, even with massive new oil revenues, Nigeria remained a very poor country in terms of per capita income. Thus, it goes without saying that a country's source of revenue is an important component of her governance. From all the scenarios alluded to above, the opinion of scholars that sources of state revenue have a major impact on patterns of state formation, human development as well as in realizing governance goals of the state, is partly vindicated but requires further empirical analysis.

\section{References}

Aboyade. (1979). Report of the Technical Commission on Revenue Allocation in Nigeria. New Nigerian Special Supplement ( $1^{\text {st }}$ December $)$ pp. iv, 1.

Adamolekun, L. (2002). Decentralisation, Sub-national Governments and Inter-governmental Relations. In Adamolekun (Ed.), Public Administration in Africa: Main Issues and Selected Country Studies (pp. 49-67). Nigeria, Ibadan: Spectrum Books.

Adebayo, A., \& Falola, T. (1991). In S. Gbadegesin (Ed.), Nigeria's second republic 1979-1983: the politicization of society. New York: Edwin Mellen.

Adesopo, A. A. (1997). Productivity of the Nigerian Tax System: 1970-1990. African Economic Research Consortium (AERC), Nairobi-Kenya, (Position Paper).

Adesopo, A. A. (2007). A Study of Inter-Governmental Fiscal Relation in Nigeria (1999-2007). Unpublished Ph.D. Thesis of the Department of Public Administration, Obafemi Awolowo University, Ile-Ife, Nigeria.

Akindele, S. T. (1995). Inter-governmental Relations as a Mechanism for coping with the complexities of Federalism. Ife Social Sciences Review, 12(1\&2), 91-101. 
Akinyemi, A. B. (1979). Federalism and Foreign Policy. In Akinyemi et al. (Eds.), Readings on Federalism (pp. 36-43). NIIA, Lagos.

Anderson, W. A. (1960). Inter-governmental Relations in Review. Minneapolis: University of Minneasota Press.

Anderson, W. A. (1973). Financing Modern Government: The Political Economy of the Public Sector. Boston: Houghto Mifflin Company. pp. 225-226.

Awa, E. O. (1976). Issues in Federalism. Nigeria, Benin: Ethiope Publishing House.

Ayo, S. B. (1986). Inter-governmental Relations and Health Care Delivery in Kwara State. In A. O. Sanda, \& O. Ojo (Eds.), Issues in the Administration of Nigerian Public Sector (pp. 76). Ile-Ife: University of Ife Press.

Barken, R. W. (2001). Illegal Flight Capital: Danger for Global Stability. International Politik, Juni(6), 34-51. (Original in German)

Bartholomew, P. C. (1972). Public Administration (3rd ed.). New Jersey, Totowa, Littlefield, Adams \& Co. pp. 44-45.

Bello-Imam, I. B., \& Agba, V. A. (2004). Fiscal Federalism, The National Question and Resource Control: Practice and Prospect. In Bello-Imam \& Obadan (Eds.), Democratic Government and Development Management in Nigeria's Fourth Republic (1999-2003) (pp. 52-74). Ibadan: CLGARDS.

Bird and Zolt. (2003). Taxation data as indicators of state-society relations: possibilities and pitfalls in cross-national research studies. Studies in Comparative International Development, 36(4), 89-115.

Brennan, G., \& Buchanan, J. M. (1980). The power of tax: analytical foundations for a fiscal constitution. Cambridge: Cambridge University Press.

Dandago, K. I. (2008). Constitutional fight against corruption in Nigeria: is it enough. International Journal on Governmental Financial Management, 23, 43-61.

Dunmoye, R. A. (2002). Resource Control: Which Way Forward? In The Nigerian Social Scientist Vol. 5 No 1 (March) Newsletter of the Social Science Academy of Nigeria; Vol. 5, No 1 (March) pp. 49-53.

Elaigwu, J. I. (1994). Ethnicity and The Federal Option in Africa. In Elaigwu J. I. et al (Eds.), Federation and Nation-Building in Nigeria: The Challenges of the $21^{\text {st }}$ Century (pp. 145-164). Abuja, NCIR.

Elazar, D. J. (1977). The Ends of Federalism: Notes Towards a Theory of Federal Political Arrangements. In M. Frenkel (Ed.), Partnership in Federalism (pp. 26). Bern: Peter Lang.

Elazar, D. J., \& John, K. (1980). Covenant, Policy and Constitutionalism. Publius, 10(fall), 3-30.

Federal Republic of Nigeria. (1978). Report of the Technical Committee on Revenue Allocation (Vol. 1). Lagos; Government Printer.

Federal Republic of Nigeria. (1980a). Report of the Presidential Commission on Revenue Allocation (Vol. 4). Minority View, Apapa, Federal Government Press.

Federal Republic of Nigeria. (1980b). Report of the Revenue Allocation Commission. Lagos: Federal Government Press Paragraphs 55 and 349.

Federal Republic of Nigeria. (1983). Report of The Study Team on the Management of Inter-governmental Relations in Federal Administration Systems. Lagos: Federal Government Press.

Hahn, H., \& Levine, C. (1980). Urban Politics: Past, Present and Future. New York: Longman.

Jinadu, L. A. (1979). A Note on the Theory of Federation. In Akinyemi et al (Eds.), op.cit pp. 13-25.

Kubeyinje, K., \& Nezianya, T. (1999). Oil: a mixed blessing for Nigerian economy. African Recovery, 13(1), 10-29.

Likita. (1999). The strategy of federalism development. New Haven, CT: Yale University Press.

Lledo, V., Schneider, A., \& Moore, M. (2003). Governance, taxes, and tax reform in Latin America. Institute of Development Studies (IDS) Working Paper 221, March 2003, England.

Lledo, V., Schneider, A., \& Moore, M. (2003). Pro-poor Tax Reform in Latin America: A Critical Survey and Policy Recommendations. Institute of Development Studies, University of Sussex.

Mamud. (2008). Governance in Indonesia: Some Comments. Working Paper, Asian Development Bank Institute, Tokyo.

Mbanefoh. (1993). Public goods and private wants. Cheltenham: Edward Edgar. 
Mfor. (2009). Aid Dependence and Governance. Working Paper of the Expert Group on Development Issues (EGDI), School of International Service, American University, Washington, D.C.

Moore, M. (2001). Political Underdevelopment: What Causes 'Bad Governance'. Working Paper. The Institute of Development Studies (IDS). https://doi.org/10.1080/14616670110050020

Nwabuese. (1983). Democracy in Nigeria: Political Scientist's View. In O. Oyediran (Ed.), Governance and Development in Nigeria. Ibadan: A. A. Publishers.

Okeke. (2004). Representation without Taxation: an essay on democracy in rural Nigeria, 1952-1990. African Studies Review, 35(1), 41-79.

Okoh. (2004). Fiscal Consolidation, Inclusive Growth and Job Creation: An Assessment of the Nigerian Budget 2004.

Olaiya, T. A. (2009). Tax Administration and Burden of Governance in Nigeria and Ghana: A Comparative Analysis. Germany: Lap-Lambert Academic Publishing.

Olowu, D. (1979). Inter-governmental Relations and Effective Local Government in Nigeria. An Extract of a Paper delivered in Oyo State House of Assembly (October).

Olowu, D. (2003). Local Democracy, Taxation and Multi-Level Governance in Africa. Draftpaper prepared for Norwegian Association for Development Research (NFU) Annual Conference on Politics and Poverty, Oslo, Norway.

Olugbemi, S. O. (1980). A System Approach to Inter-governmental Relations (IGR). Quarterly Journal of Administration, xiv(2), 111-117.

Oyefusi, A. (2007). Oil Dependence and Civil Conflicts in Nigeria. CSAE Working Paper Series 2007-09, CSAE Nairobi, Kenya.

Oyewole, A. (1980). State/Local Government Relations: A Review of Guidelines for Local Government Reform. Quarterly Journal of Administration, xiv(2), 221.

Public Service Review Commission (The Udoji Commission) Report, 1974.

Riker, W. H. (1975). Federalism. In N. Polsby, \& F. Greenstein (Eds.), Governmental Institutions and Processes (pp. 93). Addison Wesley.

Sala-i-Martin, X., \& Subramanian, A. (2003). Addressing the Natural Resource Curse: An Illustration from Nigeria. Working Paper Series WP/03/139, IMF, Washington, D.C. https://doi.org/10.3386/w9804

Schofield, R. (2004). Taxation under the early Tudors: 1485-1547. London: Blackwell Publishing Ltd. https://doi.org/10.1002/9780470758298

Shiyanbade, B. W. (2011). An Assessment of Good Governance and Corruption in Nigeria. Unpublished B.Sc. Project of the Department of Public Administration, Obafemi Awolowo University, Ile-Ife, Nigeria.

Shiyanbade, B. W. (2016). State and Local Government Joint Accounts and the Challenges of Service Delivery in Southwestern Nigeria. Unpublished M.Sc. Thesis of the Department of Public Administration, Obafemi Awolowo University, Ile-Ife, Nigeria.

Smith, M. (2007). Environmental Militarism: Burma's Extractive Industries. Greener Management International, (52), 47-61.

Suberu and Diamond. (2001). The spirit of democracy: the struggle to build free societies throughout the world. New York: Holt Paperback.

TelIa. (1999). Delegative democracy. Journal of Democracy, 5(1), 55-69.

Tinubu, B. A. (2006). Issues in Fiscal Federalism in Nigeria: The Causes and Consequences. Being a Lecture Delivered at the First Alhaji Lateef Femi Okunnnu Annual Law Lecture at Obafemi Awolowo University, Ile-Ife, Nigeria on Wednesday, $10^{\text {th }}$ May, 2006.

Vincent. (2002). Lifting oil curse: improving petroleum revenue management in sub-Saharan Africa. Washington, D. C.: International Monetary Fund (IMF).

Watts, R. L. (1972). Administration in Federal Systems. London: Hutchinson Educational pp. 8, 9-10.

Wheare, K. C. (1964). Federal Government. New York; Oxford University Press. 


\section{Copyrights}

Copyright for this article is retained by the author(s), with first publication rights granted to the journal.

This is an open-access article distributed under the terms and conditions of the Creative Commons Attribution license (http://creativecommons.org/licenses/by/4.0/). 